\section{Identifying Indoor Plant Propagation Research and Education Needs of Specialty Crop Growers}

\author{
Kristin E. Gibson ${ }^{1}$, Alexa J. Lamm ${ }^{1}$, \\ Fallys Masambuka-Kanchewa ${ }^{1}$, Paul R. Fisher ${ }^{2}$, \\ and Celina Gómez ${ }^{2}$
}

\begin{abstract}
ADDITIONAL INDEX WORDs. controlled environment, lighting, stakeholder needs, nursery, greenhouse

SUMMARY. There are economic and knowledge-based challenges that must be addressed for indoor farms to be viable in the United States despite their potential benefits. A mixed-methods approach was used to identify the needs of specialty crop growers and stakeholders interested in or currently using indoor propagation environments to grow seedlings, cuttings, and tissue-cultured plants. An online survey evaluated specialty crop growers' current use of indoor plant propagation environments and their needs related to indoor plant propagation. A focus group was then conducted to further understand the needs for indoor plant propagation by stakeholders. Industry participants were largely motivated to adopt indoor propagation environments to reduce crop losses ("shrinkage"), increase productivity per unit of land area, ensure faster germination or rooting, improve plant quality, and profit from anticipated economic benefits. Research and education priority areas identified by stakeholders included economic costs and benefits (including capital investment and energy costs), improved crop quality, production time, uniformity, reduced shrinkage, and strategies to improve light management indoors. Based on the results, research efforts must determine and prioritize the most important economic considerations and production advantages to fill important gaps in knowledge about indoor plant propagation.
\end{abstract}

I ndoor farms, which are sometimes termed plant factories or vertical farms, are controlledenvironment systems that enable year-round plant production and offer significant opportunities to help address global challenges in agriculture, such as mitigating the effects of unpredictable weather (Kwon and Lim, 2012), seasonal variation (Shimizu et al., 2020), urban encroachment (Graamans et al., 2018), and labor shortages (Shimizu et al., 2013). On a space-time

Received for publication 10 Apr. 2020. Accepted for publication 13 May 2020 .

Published online 5 June 2020.

${ }^{1}$ University of Georgia, Department of Agricultural Leadership, Education and Communication, 405 College Station Road, Athens, GA 30602

${ }^{2}$ University of Florida, Environmental Horticulture Department, 2543 Fifield Hall, Gainesville, FL 32611

This research was supported by the National Institute of Food and Agriculture under ID number USDANIFA-SCRI-006745.

K.E.G. is the corresponding author. E-mail: kristin. gibson@uga.edu.

This is an open access article distributed under the CC BY-NC-ND license (https://creativecommons.org/ licenses/by-nc-nd/4.0/).

https://doi.org/10.21273/HORTTECH04622-20 basis, multitier indoor farms can be orders of magnitude more productive than open-field production. Compared with greenhouses, environmental control of temperature, light (spectrum, intensity, and duration), humidity, and carbon dioxide in indoor farms can decrease cropping times, reduce chemical inputs, and provide opportunities to improve the quality and predictability of plant products (Kozai and Niu, 2020a). The indoor farm industry appeals to many, ranging from entrepreneurs, new and beginning farmers (i.e., young-generation farmers), and established growers looking for more sustainable production practices (Mitchell and Sheibani, 2020; Wright, 2018). However, economic viability in the United States has yet to be determined, as the number of profitable indoor farms is limited and many commercial operations in North America have struggled financially (Agrilyst, 2017; Higgins, 2016).

The expansion and prominence of the indoor farm industry has been driven by the increasing interest to promote urban food production (Takagaki et al., 2020). However, the primary focus to produce edible leafy greens for urban markets, which must compete with comparatively low-cost field-produced food crops, is at least partly responsible for the lack of financial success from earlier attempts at implementing indoor farms in the United States. In addition, uncertainty from "unproven" technology, layout and system inefficiencies, and lack of training resources have been highlighted as major barriers to adoption and profitability (Kubota, 2020; Michael, 2017). Research addressing the challenges associated with indoor farms is lacking, making technical and financial feasibility decisions difficult as the improvements associated with efficiency and cost-effectiveness of commercial indoor farms are largely unknown (Kozai and Niu, 2020b; Kwon and Lim, 2012).

Technologies developed for indoor farms can easily be applied to the production of young plants (i.e., transplants started from tissue culture, cuttings, grafts, seeds, and other propagules), which may increase the economic viability of indoor farms compared with lower-valued leafy greens. Young plants are suited for indoor farms because transplants typically have short height, short production time, high plant density, low energy demand on a per-plant basis, and high economic value (Chun and Kozai, 2000; Kozai, 2020; Nunomura et al., 2020). Ornamental young plants represent more than $10 \%$ of the $\$ 6.1$ billion floriculture industry in the United States and it is one of the segments with the highest economic growth, with a $9.2 \%$ increase from 2012 to 2017 [U.S. Department of Agriculture (USDA), 2019]. As of 2019, the total sales value of the U.S. vegetable and strawberry (Fragaria

\begin{tabular}{lccl}
\hline $\begin{array}{l}\text { Units } \\
\begin{array}{l}\text { To convert U.S. to SI, } \\
\text { multiply by }\end{array}\end{array}$ & U.S. unit & SI unit & $\begin{array}{l}\text { To convert SI to U.S., } \\
\text { multiply by }\end{array}$ \\
\hline 0.0929 & $\mathrm{ft}^{2}$ & $\mathrm{~m}^{2}$ & 10.7639
\end{tabular}


$\times$ ananassa) transplant industry was $\$ 250$ million and $\$ 166$ million, respectively (USDA, 2015, 2019). In addition, production of nursery stock liners and tissue-cultured plants are currently valued at $\$ 168$ million and $\$ 54$ million, respectively (USDA, 2015). Regardless of commodity, young-plant producers represent a significant portion of the specialty crop industry in the United States, and the quality and value of young plants directly impact overall profits of the entire industry. Therefore, research focused on indoor propagation to help maximize production efficiency of high-value young plants that have high crop loss rates, are of poor quality when produced with standard practices, or experience slow rooting, has the potential to benefit the entire specialty crop industry. Promising research has been undertaken for indoor propagation of seedlings (Park and Runkle, 2018) and cuttings (Christiaens et al., 2019; Zheng et al., 2020) that emphasizes the potential to affect survival, growth rate, and quality of young plants, also enabling researchers to understand physiological limitations of plant productivity in controlled environments.

Indoor farms are an emerging agricultural production system that would benefit from identifying social, economic, and technical barriers to adoption based on a systematic needs assessment. Therefore, the objective of this study was to identify the needs of specialty crop growers and stakeholders interested in or currently using indoor farms for plant propagation to align research efforts with industry needs. The study was guided by the following research questions: 1) what are the characteristics of indoor farms within the United States? 2) what plants are most appropriate for indoor propagation? and 3 ) what are the needs of stakeholders and specialty crop growers related to indoor propagation?

\section{Materials and methods}

A mixed-method research design was used to better understand the research and education needs of specialty crop growers and stakeholders interested in supporting, implementing, or currently using indoor plant propagation environments. An online survey was used to collect quantitative data and a focus group was conducted to collect qualitative data, providing an in-depth understanding of the issues (Tremblay, 1957).

SPECIALTY CROP GROWER SURVEY. Data were collected from specialty crop growers in Sept. 2019 using a researcher-developed online survey. Indoor propagation relies on emerging technologies currently used by only a small group of early adopters and likely to have limited recognition by most growers. Therefore, surveying a broad and general specialty crop grower audience was not considered to be an effective way to obtain deep knowledge about research needs (Etikan et al., 2016). Instead, purposive sampling was used to identify potential respondents. With guidance from a social science research team leading the research, a team of horticulture researchers and extension specialists identified 20 specialty crop growers propagating at least 100,000 transplants per year that would be aware of indoor propagation research and extension needs because they had either been featured in industry articles about current indoor farm practices, were currently trialing indoor farms, or had expressed interest in running a trial with this technology to researchers in the Floriculture Research Alliance (Erwin et al., 2012). The identified specialty crop growers were sent an email requesting their prompt response to an online survey. Three follow-up e-mails, following the Tailored Design Method (Dillman et al., 2009), were then used to obtain as many responses as possible.

The survey consisted of 19 demographic, Likert-type, and ranking items. Definitions were provided at the beginning of the survey to improve clarity and consistency in response: "The goal of the following survey is to identify perceptions of indoor propagation of young plants. 'Indoor propagation' in this survey refers to growing young plants under electric lights (without sunlight) in a climate-controlled room. 'Young plants' refers to transplants grown from seed, cuttings, or through tissue culture." Five questions were used to identify respondents' current use of indoor plant propagation environments. The first question asked respondents to indicate if they currently used small-scale, commercial-scale, or no indoor plant propagation environments. If respondents indicated they use a small-scale or commercial-scale indoor plant propagation environment, they answered specific questions about their experiences with indoor plant propagation. The specific questions asked respondents to indicate the amount of growing area in their indoor propagation space, the number of full-time employees required to manage their indoor propagation space, their use of light-emitting diodes (LEDs) in indoor farms, and the typical light intensity of photosynthetically active radiation $(P A R)$ in the indoor propagation space.

Seven questions were then used to identify respondents' needs related to indoor plant propagation. The first question asked respondents to indicate the level of importance they associated with 13 factors that could impact their decision to adopt or not adopt an indoor propagation environment. The 13 factors included the following: economic costs and benefits, increase crop uniformity, improve labor efficiency, implement automation, increase your ability to produce more in the same land area, improve overall plant quality, faster germination or rooting, faster crop time, plants are more likely to be acclimated before moving them to a greenhouse, reduce shrinkage (reduce crop losses, increase survival during rooting), increase duration of growing season, reduce pesticide use, and other. The respondents indicated the level of importance using a fivepoint Likert-type scale ( $1=$ not important at all; 2 = slightly important; $3=$ moderately important; 4 = very important; 5 = extremely important).

The second question asked respondents to indicate the level of importance they associated with 13 research topics that could provide new information that may help with their adoption or success with indoor propagation. The 13 topics included the following: automation; chemical application methods; clear option, plans, and guidelines for technology use; disease management; economic costs and benefits/return on investment; effects on crop quality, production time, uniformity, and shrinkage; fertilizer management; irrigation management; labor management; light management; pest management; training materials for staff; and temperature, humidity, and air flow management. The respondents 
indicated the level of importance using a rank order scale ( $1=$ most important; 13 = least important).

The third question asked respondents to indicate which plants were most appropriate for indoor propagation. The respondents were given six options and asked to indicate all that apply. The six options included the following: seedlings, cuttings, tissue culture, none, I don't know, and other. Four fill-inthe-blank questions asked respondents to indicate the type of young plant(s) they were most interested in propagating indoors, the species of young plant(s) they were most interested in growing in an indoor propagation environment, the specific advantages for their business with an indoor propagation environment, and the potential challenges for their business with implementing indoor propagation. The final question asked respondents to include any additional information they wanted to share about their interest in indoor plant propagation.

The survey was reviewed for face and construct validity by a panel of faculty specializing in survey design, needs assessment, and horticulture. Face validity was evaluated to determine if the instrument questions were appropriate for measuring the research objectives (Ary et al., 2014). Construct validity was assessed to determine if the instrument questions were appropriate for the determined audience and relevant to the study's objectives (Ary et al., 2014). The study was approved by the University of Florida Institutional Review Board (IRB201802820). Data from the survey were analyzed descriptively using a statistics software (SPSS Statistics 25; IBM Corp., Armonk, NY). The analysis included frequencies and percentages as well as the measures of central tendency.

STAKehOLDER FOCUS Group. After the survey was conducted, 25 stakeholders interested in supporting, implementing, or currently using indoor propagation environments were recruited to participate in a focus group to obtain deeper insight into the findings from the online survey. The focus group was conducted after the survey data had been analyzed so the information obtained would further elucidate the results. Of the 25 invited, 19 chose to attend and participate. Focus group participants were purposively selected by a team of horticulture faculty to ensure different aspects of the industry were represented in the conversation (e.g., leafy green and ornamental producers, technology and consumable developers and suppliers, breeders, among others) (Chalofsky, 1999).

The focus group was conducted by a moderator, assistant moderator, and note taker who had not previously worked with any of the participants to reduce bias. Participants were ensured of their confidentiality at the beginning of the focus group. The moderator's input was minimal, and the conversation was allowed to flow naturally using a guide. The guide was developed and reviewed by a team of faculty specializing in needs assessment, qualitative data collection, and horticulture.

Multiple opportunities for participation were arranged to gain information from all participants. The focus group was audio recorded and notes were taken to be used for triangulation purposes (Lincoln and Guba, 2002). At the end of the session, the notes were summarized for the participants to reflect on as a form of member checking (Lincoln and Guba, 2002). The audio recordings were transcribed, pseudonyms were assigned to ensure confidentiality, and the data were analyzed using coding software (MAXQDA; VERBI, Berlin, Germany), through a basic content analysis (Creswell and Creswell, 2017). Full demographics of focus group participants were not included in the results to ensure confidentiality of response because there is a small and easily identifiable number of stakeholders in the United States. Common patterns, themes, and relationships were identified in the dataset by two independent coders. The resulting data were then discussed and peer reviewed by a team of three researchers not involved in the initial coding to ensure transferability (Lincoln and Guba, 2002).

SURVEY AND FOCUS GROUP DATA INTEGRATION. Data obtained from the survey and focus group were analyzed independently and then integrated to interpret the results (Creswell and Creswell, 2017; Sandelowski, 2000). The qualitative results from the focus group were used to corroborate the quantitative survey results (Bazeley, 2012).

\section{Results and discussion}

Survey. Survey responses were obtained from 13 individuals (65\% response rate). A full demographic profile of the respondents can be viewed in Table 1 . The average respondent was male, white, and ranged in age from 35 to 64 years. Respondents represented five states and one country outside of the United States, with the largest number of respondents from Florida. All but one of the respondents had at least a 4-year college degree, and nearly half of the respondents had a graduate or professional degree. More than half of the respondents $(58 \%)$ indicated their annual sales value of young plants was between $\$ 10$ million and \$249.99 million.

Most respondents (61\%) indicated they were currently using commercial-scale indoor plant propagation environments, and the remaining 39\% indicated they do not currently rely on indoor plant propagation (Table 2). The respondents produced a large number of transplants, ranging from one grower producing " 100,000 to 499,999 ," two growers with "over 250 million" transplants per year, and five growers in the median group producing "10 million to 49.99 million" (Table 1). Survey respondents who indicated using commercial-scale indoor plant propagation environments had dedicated spaces ranging widely between 2300 and 8 million $\mathrm{ft}^{2}$ of bench or shelf space. To manage their indoor propagation space, $63 \%$ of respondents, all with spaces larger than $80,000 \mathrm{ft}^{2}$, indicated needing five or more full-time employees (Table 3 ), which could represent a large cost of production depending on the exact scale of the indoor propagation space. Mechanizing propagation processes such as seeding, transplanting, transplant quality-inspection, harvesting, and packaging could be implemented in indoor farms to reduce labor costs associated with producing thousands of young plants in a single space. However, automation is still relatively uncommon in indoor farms, as consumables and facilities have not yet been standardized; thus, equipment for automation is typically made-toorder (Shimizu et al., 2020). 
Table 1. Demographic characteristics of specialty crop grower respondents to a survey in $2019(\mathrm{~N}=13)$.

\begin{tabular}{lc}
\hline Demographic characteristic & Grower responses (\%) \\
\hline Sex & \\
Male & 76.9 \\
Female & 23.1 \\
Race & \\
Asian or Pacific Islander & 7.7 \\
Black of African American & 7.7 \\
White & 76.9 \\
Other & 7.7 \\
Hispanic/ Latino Ethnicity & 7.7 \\
Age (years) & \\
35-44 & 46.2 \\
$45-54$ & 23.1 \\
55-64 & 30.8 \\
Education & \\
2-year college degree & 7.7 \\
4 -year college degree & 46.2 \\
Graduate or professional degree & 46.2 \\
U.S. State & \\
Florida & 30.8 \\
Michigan & 23.1 \\
New Jersey & 7.7 \\
North Carolina & 23.1 \\
Virginia & 7.7 \\
Outside of the United States & 7.7 \\
Annual sales value of young plants & \\
Less than \$100,000 & 8.3 \\
\$100,000 to \$499,999 & 8.3 \\
\$500,000 to \$999,999 & 8.3 \\
\$10 million to \$49.99 million & 16.7 \\
\$50 million to \$99.9 million & 50.0 \\
\$100 million to \$249.99 million & 0 \\
\hline
\end{tabular}

Table 2. Indoor technologies used by specialty crop grower respondents to a survey in $2019(\mathrm{~N}=13)$.

\begin{tabular}{lc}
\hline Indoor propagation environments used by growers & Grower responses (\%) \\
\hline Small-scale trial indoor propagation environment & 0 \\
Commercial-scale indoor propagation environment & 61.5 \\
None of the above & 38.5 \\
\hline
\end{tabular}

Seedlings, cuttings, and tissuecultured plants were all considered appropriate for indoor propagation by $31 \%$ of the survey respondents (Table 4); however, most respondents were interested in growing tissue-cultured young plants indoors, followed by seedlings and cuttings. Three survey respondents indicated the species they were most interested in propagating indoors was hemp (Cannabis sativa). Others referred to a various species of interest, including ornamental plants [e.g., geranium (Pelargonium sp.), gerbera (Gerbera jamesonii), pansy (Viola tricolor var. hortensis), hydrangea (Hydrangea sp.), chrysanthemum (Dendrandema $\times$ grandiflora), poinsettia (Euphorbia pulcherrima), begonia (Begonia sp.), coral bells (Heuchera sp.), sage (Salvia sp.), spurge (Euphorbia sp.), hellebore (Helleborus sp.), leopard plant (Ligularia sp.), primrose (Primula sp.), carnation (Dianthus sp.), petunia (Petunia sp.), pentas (Pentas sp.), cone flower (Echinacea sp.), lisianthus (Lisianthus sp.), and other
Table 3. Employees needed by specialty crop grower respondents to a survey in 2019 to manage indoor spaces $(\mathrm{N}=13)$.

\begin{tabular}{lc}
\hline $\begin{array}{l}\text { Employees } \\
\text { needed (no.) }\end{array}$ & Grower responses (\%) \\
\hline 0 & 0 \\
1 & 0 \\
2 & 37.5 \\
3 & 0 \\
4 & 0 \\
5 or more & 62.5 \\
\hline
\end{tabular}

Table 4. Types of plants specialty crop grower respondents to a survey in 2019 believed were best suited for indoor plant propagation $(\mathrm{N}=13)$.

\begin{tabular}{lc}
\hline Type of plant & Grower responses (\%) \\
\hline Tissue culture & 69.2 \\
Seedlings & 61.5 \\
Cuttings & 53.8 \\
\hline
\end{tabular}

vegetative and tropical annuals], hard-to-root woody crops [e.g., loropetalum (Loropetalum sp.), crape myrtle (Lagerstroemia sp.), blueberry (Vaccinium sp.), and koreanspice viburnum (Viburnum carlesii)], lettuce (Lactuca sativa), and baby leaf greens.

Most of survey respondents (88\%) who had indicated using commercial-scale indoor plant propagation environments used LED lighting. The light intensity used for indoor propagation was reportedly between 15 and $6000 \mu \mathrm{mol} \cdot \mathrm{m}^{-2} \cdot \mathrm{s}^{-1}$. This unrealistic range highlights a need for improved training and understanding of the differences among light units commonly used in horticulture (intended variously to describe radiation level in terms of $P A R$, electrical energy, visible light, and total radiation), given that the typical light intensity for indoor propagation ranges from 100 to 300 $\mu \mathrm{mol} \cdot \mathrm{m}^{-2} \cdot \mathrm{s}^{-1}$ (Kozai, 2020).

Survey respondents indicated one primary concern when deciding whether to adopt indoor plant propagation environments was to reduce shrinkage (Table 5). Shrinkage refers to the economic cost of product that is not successfully sold. A previous survey of ornamental plant growers found that losses tend to be higher for seedling plugs (15\%) and rooted cuttings $(12 \%)$ compared with finished 
Table 5. Importance of factors in specialty crop grower survey respondent's adoption decision related to using indoor propagation environment as determined in $2019(\mathrm{~N}=13)$.

\begin{tabular}{|c|c|c|c|c|c|c|c|}
\hline Factor & $\begin{array}{c}\text { Not important } \\
\text { at all }(\%)\end{array}$ & $\begin{array}{c}\text { Slightly } \\
\text { important (\%) }\end{array}$ & $\begin{array}{c}\text { Moderately } \\
\text { important (\%) }\end{array}$ & $\begin{array}{c}\text { Very } \\
\text { important (\%) }\end{array}$ & $\begin{array}{c}\text { Extremely } \\
\text { important (\%) }\end{array}$ & Mean $^{\mathrm{z}}$ & SD \\
\hline Reduce shrinkage & 8.3 & 0 & 0 & 16.7 & 75.0 & 4.50 & 1.17 \\
\hline $\begin{array}{l}\text { Increase your ability to produce } \\
\text { more in the same land area }\end{array}$ & 0 & 8.3 & 0 & 33.3 & 58.3 & 4.42 & 0.90 \\
\hline Faster germination or rooting & 8.3 & 0 & 0 & 33.3 & 58.3 & 4.33 & 1.16 \\
\hline Economic costs and benefits & 0 & 8.3 & 8.3 & 25.0 & 58.3 & 4.33 & 0.99 \\
\hline Faster crop time & 8.3 & 0 & 25.0 & 16.7 & 50.0 & 4.00 & 1.28 \\
\hline Increase crop uniformity & 8.3 & 8.3 & 0 & 41.7 & 41.7 & 4.00 & 1.28 \\
\hline Reduce pesticide use & 0 & 16.7 & 25.0 & 16.7 & 41.7 & 3.83 & 1.19 \\
\hline Increase duration of growing season & 8.3 & 8.3 & 16.7 & 25.0 & 41.7 & 3.83 & 1.34 \\
\hline $\begin{array}{l}\text { Plants are more likely to be } \\
\text { acclimated before moving } \\
\text { them to a greenhouse }\end{array}$ & 8.3 & 0 & 25.0 & 41.7 & 25.0 & 3.75 & 1.14 \\
\hline
\end{tabular}

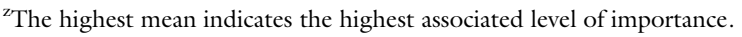

flowering plants $(6 \%)$ because of factors such as poor germination and rooting success (Fisher et al., 2016). Shrinkage in greenhouse propagation of hard-to-root young plants such as blueberry microcuttings can sometimes exceed 70\% (T. Strode, personal communication). A transitional phase in which young plants with significant losses are grown indoors could rapidly increase the return on investment in indoor propagation if shrinkage can be reduced (Kozai, 2020; Zobayed, 2020a). Survey respondents were also interested in the ability to produce more plants in the same land area, faster germination and rooting rates, economic advantages, and improved overall plant quality (Table 5). Survey respondents were least interested in implementing automation, but conversely were fairly concerned about increasing labor efficiency.

In response to an open-ended question, survey respondents listed the following as specific business advantages they believed could be attained with an indoor propagation environment: uniformity, year-round quality, better space utilization, profitability, reduced rooting times, yield optimization, and elimination of pest breakouts. In contrast, they listed the following as perceived business challenges with indoor propagation: disease pressure, learning curve, temperature control, ongoing maintenance, and identifying a location. It is widely accepted that indoor farms benefit from qualified and skilled personnel to maximize the advantages of controlled-environment production, and attempts to provide training about new technologies and utilization methods for indoor farms exist within several academic and industry groups in Asia (Yamaguchi, 2020); however, training and education opportunities for U.S. growers are mainly limited to field or greenhouse crop production (Kubota, 2020). Growers would presumably benefit from training materials that could minimize risk from potential production challenges as the ones described previously. Despite this apparent benefit, the development of training materials for staff was listed as the least important focus direction for researchers (Table 6).

Survey respondents indicated the most important focus for new research should relate to economic costs and benefits/return on investment, followed by efforts aiming to improve crop quality, production time, uniformity and shrinkage, and strategies to improve light management indoors (Table 6). Kwon and Lim (2012) identified the need for research to overcome economic challenges with energy-efficient solesource lighting as a priority for indoor farms, and Sugano (2015) suggested that costs to install and operate indoor farms must be reduced to ensure financial viability. To our knowledge, there have been limited economic analyses of indoor farms, and those available have focused on leafy green production (Fang, 2020; Inada, 2016). Capital investment and solesource lighting costs are easily calculated for case study analyses. However, cost data are especially lacking on labor needs, energy requirements, and economic modeling for proper environmental control in indoor propagation. Potential economic benefits from using indoor farms in propagation include reduced shrinkage, lower losses from pest and disease pressure (and its associated management costs), increased potential for automation, traceability and biosecurity, and improved quality from better plant performance during hardening off and posttransplant stages (e.g., increased survival, uniformity, growth rate, economic yield, and reduced crop time) (Kozai, 2020; Nunomura et al., 2020). In addition, because plant responses to indoor propagation can be highly dependent on species and sometimes cultivar, several of the factors identified above would need to be quantified for individual crop species and cultivars in complete economic analyses.

Three survey respondents shared additional information about their interest with indoor propagation research. One respondent explained they were interested in "how $[\ldots]$ technology [...] can contribute to the development of the industry." 
Table 6. Specialty crop grower respondents to a survey ranking of factors for new indoor plant propagation research in $2019(\mathrm{~N}=13)$.

\begin{tabular}{lrrr}
\hline Factor & Mean & SD & Rank \\
\hline Economic costs and benefits/return on investment & 3.25 & 2.26 & 1 \\
Effects on crop quality, production time, uniformity, shrinkage & 3.58 & 2.78 & 2 \\
Light management & 5.33 & 3.50 & 3 \\
Automation & 5.50 & 4.12 & 4 \\
Clear options, plans, and guidelines for technology use & 5.83 & 3.71 & 5 \\
Temperature, humidity, and air flow management & 6.83 & 4.39 & 6 \\
Labor management & 7.08 & 4.06 & 7 \\
Disease management & 7.33 & 1.56 & 8 \\
Irrigation management & 7.50 & 2.68 & 9 \\
Fertilizer management & 8.67 & 2.50 & 10 \\
Chemical application methods (pesticides, micronutrients, & 9.17 & 2.69 & 11 \\
$\quad$ plant growth regulators) & & & \\
Pest management & 9.50 & 2.47 & 12 \\
Training materials for staff & 11.42 & 2.47 & 13 \\
\hline
\end{tabular}

Another respondent suggested "[with] a surge on indoor propagation and production facilities, $[\ldots]$ more interest and focus on leafy veggies and cannabis and lack of information and resources on ornamental crops." The third survey respondent highlighted the importance of research addressing proper humidity control for indoor plant propagation. These specific priorities align well with research and development challenges previously identified for the next generation of indoor farms, which when resolved, could help expand the diversity of plant production systems beyond open fields and greenhouses (Kozai and Niu, 2020b).

FocUs GROUP. Focus group participants identified research needs for indoor plant propagation, including light management, crop quality, production time, uniformity and shrinkage, and temperature, humidity, and airflow management. More specifically, when discussing light management strategies, focus group participants were interested in increasing light-use efficiency, improving concentration and composition of functional components in plants with light quality, and on the economics of using sole-source lighting. Participant K, who managed a wholesale supply company, explained, "[...] I want to figure out how we do more with less because if we can do more with less light, then we immediately have an impact on temperature, humidity, and airflow, [...]." Participant I, who managed an indoor farm, also commented on light management when he stated, "lettuce, it's important $[\ldots]$ we've seen recent studies looking at using blue light $[\ldots]$ but what about the nutritive part of the plant, and obviously that's the vital elementals of why we do food crops." Participant B, who managed an organic herb company, posed questions about light management, asking " $[\ldots]$ what is your optimum light levels, what is your maximum for maximum production? Where are you wasting your money? Where are you investing your money properly and your capital costs? And how does that affect your operating costs? How far can you push things? How [...] fast can you do your turnover of plants without hurting quality?" Participant $\mathrm{F}$, who was a greenhouse propagator, also addressed light management by stating, "for light management, I think one thing that would be important for us to $[\ldots]$ really start to question the wavelengths $[\ldots]$ seeing what the response is to these different spectrums $[\ldots]$." Recent research has shown that far-red radiation with LEDs has significant potential to promote adventitious root formation in unrooted cuttings (Christiaens et al., 2019) and may increase seedling growth under light-limited conditions (Meng and Runkle, 2019) such as the ones used for indoor propagation. However, according to Mitchell and Sheibani (2020), long-term commercial profitability in indoor farms supported by specific LED fixtures and light-qualities for particular species or cultivars remains to be determined by economies of scale.

When discussing crop quality, production time, uniformity, and shrinkage, focus group participants were mostly interested in reducing crop time. For example, Participant R, who worked for a seed breeding company, suggested, “[...] people have talked about reducing crop time by a week or two by putting the plants under optimum systems [...] So if it is actually true $[\ldots]$, then we can actually catch up on losses." In agreement with this comment, others have suggested that indoor farms can provide significant advantages for accelerating breeding programs, as multiple generations of plants could be produced each year under optimal environmental conditions, enabling scientists to rapidly release new cultivars with high growth rates (Kozai and Niu, 2020b). When discussing temperature, humidity, and airflow management, focus group participants were particularly interested in improving environmental uniformity. For example, Participant A, who managed an indoor farm, said "[...] we create a macroclimate in the whole facility and then we create microclimates within the growing module itself $[\ldots]$ we're not trying to keep the whole facility $[\ldots]$ at this really fine environmental [setpoint] [...]." Furthermore, Participant K, who managed a wholesale supply company, asked, "[...] almost every farm, while the configurations are maybe similar, almost every farm is different $[\ldots]$ how do we find something that is uniform enough $[\ldots]$ how do we make this apply to everyone?"

Focus group participants identified a broad range of crops they were interested in propagating indoors. Among the crops identified, blueberry, hemp, hibiscus (Hibiscus rosasinensis), lettuce, strawberry, and tomato (Solanum lycopersicum) were highlighted as those with the most potential for indoor propagation. More specifically, when discussing lettuce, Participant B, who managed an organic herb company, explained “ [lettuce is] the most cost-effective and most widely used product out there that can be cost-effective growing in a vertical farming environment or indoor farming environment. So of course, it becomes really important for plant factory propagation." Currently, a limited number of indoor farms are growing vegetable seedlings or herbs in the United States, and a few more producing leafy greens to 
promote local food production. However, indoor propagation for vegetable and ornamental crops is expected to increase in the coming years, particularly for greenhouse finishing (Kubota, 2020). According to a whitepaper recently published by a trade magazine, indoor propagation is one of the top eight greenhouse technology trends in 2020, with significant potential to help growers standardize propagation before transplanting in the greenhouse (Greenhouse Grower, 2020).

Several growers expressed concerns about potential challenges with maintaining multiple microclimates for different crop species. Although most research has focused on systematically evaluating environmental requirements of specific crops that are suited for indoor farms (Kozai and Niu, 2020a), indoor propagation would entail the production of multiple crop species with different morphologies and environmental requirements at a given time within the same production space (Adegbola et al., 2019). The diversity in crop uniformity with indoor propagation highlights the need for research to define environmental conditions that will maximize production for multiple species of young plants, and those are expected to differ between seedlings and vegetatively propagated crops. Furthermore, economic analyses need to define the return on investment for propagating multiple crop species indoors, as benefits from indoor farms are likely to differ based on shrinkage reduction or production advantages from improved product quality, which are likely to be species-specific (Christiaens et al., 2016; Meng and Runkle, 2019; Zheng et al., 2020).

Focus group participants expressed nterest in hemp propagation research, but there are current barriers that may exist in securing funding for hemp research. The unevenness in genetics used for hemp production proves to be problematic for optimization in indoor farms, and the use of diverse propagation methods (seed, unrooted cuttings, or tissuecultured plants) contribute to the difficulty of developing protocols that can ensure consistency with cannabinoid content (Chandra et al., 2010). Nevertheless, there are significant advantages to producing indoor-grown transplants for different phytopharmaceutical purposes, as it is currently difficult to consistently obtain highquality medicinal plants through conventional propagation and production methods (Goto, 2020; Zobayed, $2020 \mathrm{~b}$ ). Therefore, indoor propagation of medicinals could provide good business opportunities for U.S. specialty crop growers, as they typically have a higher value per unit dry weight than most leafy greens or ornamental plants.

Focus group participants identified the ability to produce yearround, better or increased yield in controlled environments, and crop uniformity as primary benefits of using indoor plant propagation environments. Participant J, who worked for a company specializing in perennial ornamental plant production, said, "trying to light an entire greenhouse is very expensive, $[\ldots]$ it's maybe more efficient [...] [for] a vertical indoor setup $[\ldots]$, and we can produce and propagate cuttings throughout the winter time, which we normally can't do in our greenhouses." Participant R, who worked for a seed breeding company, discussed environmental effects on yield, "[...] we have an indoor seed testing facility, so these are indoor rooms [...] Then we grow our greenhouse situation. The exact same seed [and] often times we get lesser yields. [...] We understand that our indoor system is much more efficient. We just are not able to translate that into a greenhouse production system, because of the fluctuations in the environment. We actually have solid data, and for certain varieties, we get much better results in the indoor system." Participant N, who managed an indoor farm company, discussed uniformity stating, "[...] success is programmable. Because of the uniform temperatures, [...] It makes [indoor propagation] a very reliable way of growing plants. [...] The uniformity is greatly improved $[\ldots]$ Now, we can plant everything [...]." Year-round production of high-quality transplants that are physiologically and morphologically uniform regardless of weather is one of the single most important advantages of indoor propagation (Chun and Kozai, 2000; Kozai, 2020). However, commercial implementation of indoor farms for propagation requires the development of appropriate protocols to maximize production and profitability.

Focus group participants also identified perceived challenges of using an indoor propagation environment, such as economic considerations, efforts to manage multiple macro- and microclimates, and costs of unused space. For example, Participant A, who managed an indoor farm, discussed costs associated with managing multiple environments, "It is expensive, $[\ldots]$ some of the smaller farmers they don't have access to [a] plant factory, they might want the outcomes, they might want those high-quality plants, they might want it to be conditioned to be certain things, $[\ldots]$ but they can't afford what it costs to put in a plant factory." Participant R, who worked for a seed breeding company, also discussed challenges of managing multiple environments, "[...] with indoor propagation, there is a lot of variability between shelf to shelf, distance from the lights. We just presume that this microclimate is perfect and perfectly uniform, but it is not. It poses a lot of challenges."

In conclusion, this study identified needs of specialty crop stakeholders interested in supporting, implementing, or currently using indoor plant propagation environments. Overall, the findings suggested there is a need for education about the opportunities and challenges with indoor plant propagation. Most research to date has focused on using indoor farms for leafy green production, and information is lacking about the potential to leverage indoor farm technologies to maximize production efficiency of high-value young plants. Stakeholders are interested in technologies that can improve crop quality and uniformity, reduce production time and shrinkage, and optimize light management during propagation. Plants that have high crop loss rates, are of poor quality when produced with standard practices, or experience slow rooting were highlighted as priorities to propagate indoors. Specifically, there is interest in improving propagation practices for tissue-cultured young plants, followed by seedlings and unrooted cuttings. However, due to the different requirements in environmental conditions (e.g., light and temperature) and production 
practices (e.g., mist frequency and nutrition) of these transplant types, research must systematically identify growth and developmental limits of young plants to improve resource use efficiency, which is a critical factor to balance economic viability of indoor farms.

Findings from this study confirmed the perception that indoor farms are more efficient for yearround, high-quality transplant production than greenhouses. However, commercial implementation of indoor plant propagation will require the development of appropriate protocols to maximize production and profitability, which based on the results from this study, must be prioritized by research efforts to fill important gaps in knowledge. A systems-based, transdisciplinary approach that can draw on the expertise of several field experts is needed to address the needs of industry stakeholders. Research and outreach activities that bring together socioeconomists, engineers, plant scientists, and extension specialists who can work closely with stakeholders could help identify limiting factors with the goal of solving technical and economic issues affecting young-plant production. Collaborative efforts could include improvements in system designs to increase yield per square foot week, environmental optimization to reduce shrinkage and seasonality, improvements in resource-use efficiency and product quality, automation implementation to reduce labor costs, and facilitating the development of training materials, among others. Improving indoor plant propagation processes will further support the viability of the controlledenvironment industry as it develops in the United States. However, as suggested by the results of this study, a strategic plan encompassing stakeholder needs must be implemented to maximize the benefits and enable adoption of indoor plant propagation environments.

\section{Literature cited}

Adegbola, Y.U., P.R. Fisher, and A.W. Hodges. 2019. Economic evaluation of transplant robots for plant cuttings. Scientia Hort. 246:237-243.

Agrilyst. 2017. State of indoor farming 2017. 20 Mar. 2019. <https://artemisag. com/wp-content/uploads/2019/06/ stateofindoorfarming-report-2017.pdf>.

Ary, D., L.C. Jacobs, C.K. Sorensen, and D.A. Walker. 2014. Introduction to research in education. Wadsworth Cengage Learning, Belmont, CA.

Bazeley, P. 2012. Integrative analysis strategies for mixed data sources. Amer. Behav. Sci. 56:814-828.

Chandra, S., H. Lata, I.A. Khan, Z. Mehmedic, and M.A. ElSohly. 2010. Assessment of cannabinoids content in micropropagated plants of Cannabis sativa L. and their comparison with conventionally propagated plants and mother plant during developmental stages of growth. Planta Med. 76:743-750.

Chalofsky, N. 1999. How to conduct focus groups. Amer. Soc. Training Dev., Alexandria, VA.

Christiaens, A., B. Gobin, and M.C. Van Labeke. 2016. Light quality and adventitious rooting: A mini-review. Acta Hort. 1134:385-393.

Christiaens, A., B. Gobina, J. Van Huylenbroeckb, and M. Van Labeke. 2019. Adventitious rooting of chrysanthemum is stimulated by a low red:far-red ratio. J. Plant Physiol. 236:117-123.

Chun, C. and T. Kozai. 2000. Closed transplant production system at Chiba University, p. 20-27. In: C. Kubota and C. Chun (eds.). Transplant production in the 21 st century. Springer, Dordrecht, The Netherlands.

Creswell, J.W. and J.D. Creswell. 2017. Research design: Qualitative, quantitative, and mixed method approaches. Sage Publ., Thousand Oaks, CA.

Dillman, D.A., J.D. Smyth, and L.M. Christian. 2009. Internet, mail, and mixed-mode surveys: The tailored design method. Wiley, Hoboken, NJ.

Erwin, J., J. Faust, P. Fisher, C. Hall, J. Frantz, E. Runkle, and J. Dole. 2012. The Floriculture Research Alliance: Making a difference. GrowerTalks 2012(Nov.): 80,82 .

Etikan, I., S.A. Musa, and R.S. Alkassim. 2016. Comparison of convenience sampling and purposive sampling. Amer. J. Theor. Appl. Stat. 5:1-4.

Fang, W. 2020. PFAL business and R\&D in Asia and North America: Status and perspectives, Taiwan, p. 39-51. In: T. Kozai, G. Niu, and M. Takagaki (eds.). Plant factory: An indoor vertical farming system for efficient quality food production. 2nd ed. Academic Press, San Diego, CA.

Fisher, P.R., J.C. Vallejo, A.W. Hodges, and C.R. Hall. 2016. Tracking losses in floriculture crop production. Acta Hort. 1132:161-166.

Graamans, L., B. Esteban, A.V.D. Dobbelsteen, I. Tsafaras, and C. Stanghellini. 2018. Plant factories versus greenhouses: Comparison of resource use efficiency. Agr. Syst. 160:31-43.

Goto, E. 2020. Production of pharmaceuticals in a specially designed plant factory, p. 251-257. In: T. Kozai, G. Niu, and M. Takagaki (eds.). Plant factory: An indoor vertical farming system for efficient quality food production. 2nd ed. Academic Press, San Diego, CA.

Greenhouse Grower. 2020. 8 Greenhouse technology trends for 2020. 2 Feb. 2020. <https://www.greenhousegrower.com/ technology/new-whitepaper-8-greenhousetechnology-trends-for-2020/>.

Higgins, C. 2016. Current status of commercial vertical farms with LED lighting market in North America, p. 309-315. In: T. Kozai, K. Fujiwara, and E.S. Runkle (eds.). LED lighting for urban agriculture. Springer Nature, Heidelberg, Germany.

Inada, S. 2016. Selected commercial PFALS in Japan and Taiwan, SPREAD Co., Ltd., p. 355-362. In: T. Kozai, G. Niu, and M. Takagaki (eds.). Plant factory: An indoor vertical farming system for efficient quality food production. 2nd ed. Academic Press, San Diego, CA.

Kozai, T. 2020. Transplant production in closed systems, main components and their functions, p. 299-304. In: T. Kozai, G. Niu, and M. Takagaki (eds.). Plant factory: An indoor vertical farming system for efficient quality food production. 2nd ed. Academic Press, San Diego, CA.

Kozai, T. and G. Niu. 2020a. Role of the plant factory with artificial lighting (PFAL) in urban areas, p. 8-34. In: T. Kozai, G. Niu, and M. Takagaki (eds.). Plant factory: An indoor vertical farming system for efficient quality food production. 2nd ed. Academic Press, San Diego, CA.

Kozai, T. and G. Niu. 2020b. Challenges for the next-generation PFALs, p. 463469. In: T. Kozai, G. Niu, and M. Takagaki (eds.). Plant factory: An indoor vertical farming system for efficient quality food production. 2nd ed. Academic Press, San Diego, CA.

Kubota, C. 2020. PFAL business and R\&D in Asia and North America: Status and perspectives, North America, p. 35-42. In: T. Kozai, G. Niu, and M. Takagaki (eds.). Plant factory: An indoor vertical farming system for efficient quality food production. 2nd ed. Academic Press, San Diego, CA.

Kwon, S. and J. Lim. 2012. Improvement of energy efficiency in plant factories 
through the measurement of plant bioelectrical potential. Info. Cont. Auto. Robotics 132:641-648.

Lincoln, Y.S. and E.G. Guba. 2002. Judging the quality of case study reports, p. 205-216. In: A.M. Huberman and M.B. Miles (eds.) The qualitative researcher's companion. Sage Publ., Thousand Oaks, CA.

Meng, Q. and E.S. Runkle. 2019. Far-red radiation interacts with relative and absolute blue and red photon flux densities to regulate growth, morphology, and pigmentation of lettuce and basil seedlings. Scientia Hort. 255:269-280.

Michael, C. 2017. 9 Reasons why vertical farms fail. 2 Apr. 2019. <https://medium. com/bright-agrotech/9-reasons-whyvertical-farms-fail-244deaecd770>.

Mitchell, C.A. and F. Sheibani. 2020. LED advancements for plant factory artificial lighting, p. 167-184. In: T. Kozai, G. Niu, and M. Takagaki (eds.). Plant factory: An indoor vertical farming system for efficient quality food production. 2nd ed. Academic Press, San Diego, CA.

Nunomura, O., T. Kozai, K. Shinozaki, and T. Oshio. 2020. Seeding, seedling production and transplanting, p. 285297. In: T. Kozai, G. Niu, and M. Takagaki (eds.). Plant factory: An indoor vertical farming system for efficient quality food production. 2nd ed. Academic Press, San Diego, CA.

Park, Y. and E. Runkle. 2018. Spectral effects of light-emitting diodes on plant growth, visual color quality, and photosynthetic photon efficacy: White versus blue plus red radiation. PLoS One 13(8):e0202386.

Sandelowski, M. 2000. Combining qualitative and quantitative sampling, data collection, and analysis techniques in mixed-method studies. Res. Nurs. Health 23:246-255.

Shimizu, H., H. Nakashima, J. Miyaska, and K. Ohdoi. 2013. Current state and research trend in light environment for plant factory. Proc. Sensing Technol. Biomaterial Food Agr. 888104.

Shimizu, H., K. Fukuda, Y. Nishida, and T. Ogura. 2020. Automated technology in plant factories with artificial lighting, $\mathrm{p}$. 377-382. In: T. Kozai, G. Niu, and M. Takagaki (eds.). Plant factory: An indoor vertical farming system for efficient quality food production. 2nd ed. Academic Press, San Diego, CA.

Sugano, M. 2015. Elemental technologies for realizing a fully-controlled artificial light-type plant factory. 12th Intl. Conf. Expo on Emerging Technologies for a Smarter World. p. 1-5.

Takagaki, M., H. Hara, and T. Kozai. 2020. Micro- and mini-PFALs for improving the quality of life in urban areas, p. 117-128. In: T. Kozai, G. Niu, and M. Takagaki (eds.). Plant factory: An indoor vertical farming system for efficient quality food production. 2nd ed. Academic Press, San Diego, CA.

Tremblay, M.A. 1957. The key informant technique. A non-ethnographic application. Amer. Anthropol. 59:688-701.

U.S. Department of Agriculture. 2015. Census of horticultural specialties (2014). Volume 3 Special Studies Part 3 AC-12SS-3. 20 Mar. 2019. <https://www.nass. usda.gov/Publications/AgCensus / 2012/Online_Resources/Census_of_ HoHorticultu_Specialties/HORTIC. pdf>.
U.S. Department of Agriculture. 2019. Floriculture crops 2018 summary. U.S. Dept. Agr., Natl. Agr. Stat. Serv. ISSN: 1949-0917. 20 Feb. 2020. <https://www. nass.usda.gov/Publications/Todays_ Reports/reports/floran19.pdf>.

Wright, J. 2018. A look beyond the hype of vertical farming. 1 Apr. 2019. <https://www.greenhousegrower.com/ technology/a-look-beyond-the-hype-ofvertical-farming $/>$.

Yamaguchi, T. 2020. Education, training, and business workshops and forums on plant factories, p. 397-415. In: T. Kozai, G. Niu, and M. Takagaki (eds.). Plant factory: An indoor vertical farming system for efficient quality food production. 2nd ed. Academic Press, San Diego, CA.

Zheng, L., K. Steppe, and M. Van Labeke. 2020. Spectral quality of monochromatic LED affects photosynthetic acclimation to high-intensity sunlight of chrysanthemum and spathiphyllum. Physiol. Plant. 169:10-26.

Zobayed, S. 2020a. Transplant production in closed systems, blueberry, p. 318-323. In: T. Kozai, G. Niu, and M. Takagaki (eds.). Plant factory: An indoor vertical farming system for efficient quality food production. 2nd ed. Academic Press, San Diego, CA.

Zobayed, S. 2020b. Medicinal components, p. 245-249. In: T. Kozai, G. Niu, and M. Takagaki (eds.). Plant factory: An indoor vertical farming system for efficient quality food production. 2nd ed. Academic Press, San Diego, CA. 